\title{
The Effect of Transportation Benefits on Health and Consumption Among the Elderly: Quasi- Experimental Evidence from Urban China
}

Ting Yin

Hitotsubashi University

\section{Zhigang Yin}

Shanghai Research Center on Aging

Junchao Zhang ( $\nabla$ zhang@econ.niigata-u.ac.jp )

Niigata University https://orcid.org/0000-0002-3714-6164

\section{Article}

Keywords: transportation subsidy, health, regression discontinuity

Posted Date: October 1st, 2021

DOI: https://doi.org/10.21203/rs.3.rs-951154/v1

License: (c) (i) This work is licensed under a Creative Commons Attribution 4.0 International License.

Read Full License 


\title{
The Effect of Transportation Benefits on Health and
}

\author{
Consumption Among the Elderly:
}

\section{Quasi-Experimental Evidence from Urban China *}

\author{
Ting Yin† Zhigang Yinł Junchao Zhang§
}

September 30, 2021

\begin{abstract}
This study estimates the causal effect of transportation subsidies or similar benefits on the health of the elderly. We exploit a discontinuity in the probability of receiving transportation benefits induced by an age-based policy to take account of the endogeneity of treatment status. Our baseline IV results indicate that receiving public transportation benefits significantly improves elderly people's health condition by approximately 10 percentage points. The results are robust under different specifications and placebo tests. Further tests on possible channels show that the health effect is driven by increasing food consumption and health care utilization, but not by the amount of exercise done.

JEL classification: J14; I18; R48

KEY WORDS: transportation subsidy, health, regression discontinuity

\footnotetext{
*This study is conducted as a part of the project "Economic Analysis of the Development of the Nursing Care Industry in China and Japan" undertaken at the Research Institute of Economy, Trade and Industry(RIETI).

${ }^{\dagger}$ Hitotsubashi University, 2-1 Naka, Kunitachi, Tokyo 186-8601, Japan

$\ddagger$ Shanghai Research Center on Aging

§Niigata University, 8050 Ikarashi 2-no-cho, Nishi-ku, Niigata, 950-2181, JAPAN E-mail address: zhang@econ.niigata-u.ac.jp
} 


\section{Introduction}

Public transportation is a key component of our lives that offers a safer, more economical, and more environmentally friendly transit choice. The demands on public transit have increased rapidly over the last decade in the context of an aging population. More than one-fifth of Americans over age 65 do not drive due to poor health, limited physical or mental abilities, concerns over safety, or lack of access to a car (Bell and Cohen, 2009). Would public transit be a better alternative for them than personal vehicles? On the one hand, public transit is supposed to reduce air pollution and traffic congestion (Anderson, 2014), increase mobility (Green et al., 2014), and thus improve public health. On the other hand, promoting public transit requires a huge amount of subsidies to pay for operating costs above passenger fare revenues received. According to Parry and Small (2009), average passenger fare subsidies account for $65 \%$ of operating costs across the twenty largest transit systems in the U.S. Despite the huge cost of granting them, reduced fare and free ride permits for senior citizens and individuals with disabilities are offered in many cities. But do these public transit programs really benefit citizens' health?

The transportation literature has mainly focused on the impact of transit benefits on people's travel behavior, while its causal impact on people's health remains unknown. Coronini-Cronberg et al. (2012) studied the impact of a free elderly bus pass on active travel and regular walking in England, and found that having a free pass is positively associated with incidental physical activity. Webb et al. (2011) also reports similar results for other parts of England. Edwards et al. (2013) studied the impact of free bus travel for young people in London. However, he found little impact on active travel overall. Bueno et al. (2017) studied employees' travel behavior using data from New York and 
New Jersey, where employer-funded benefits for transit passes and bike reimbursements could be substituted for personal vehicle use.

However, it is difficult to evaluate the causal impact of transportation benefits on public health. Potential endogeneity issues are as follows: (1) Omitted variable bias: If unobserved factors are common between subsidy participation and health, then the effect of transportation benefits on health is biased. Supposing that unobserved health awareness is both positively correlated to subsidy participation and health, then the estimates would be upwardly biased; (2) Self-selection: Generally, transportation benefits are not mandatory. Even when a person is eligible for a subsidy, he has to apply to participate. If an elderly person with a low budget self-selects himself into treatment, then the marginal health impact will likely be exaggerated. Craig et al. (2012) points out that natural experiments are necessary for policy evaluation in the field of public health.

Furthermore, multicollinearity among eligible ages for transit, retirement, and health care benefits makes the impact of transportation subsidies ambiguous or unidentifiable. For instance, in the U.S., elderly people who are eligible for reduced fare permits (age 65 or older) have higher chance of being retired, as the full retirement age ranges from 65 to 66 for this cohort $^{1}$. At the same time, senior citizens become eligible for the Medicare program, which basically covers hospital and medical insurance for all people who are 65 or older. Any estimates solely relying on variation in age would capture a mixture of these policies in U.S. Isolating the impact of transit benefits from other aging policies is a near-impossible task, as multiple aging benefits are given at a certain age simultaneously.

\footnotetext{
${ }^{1}$ As of 2015
} 
This paper contributes to the literature in the following three ways. First, this paper includes a credible identification strategy to evaluate the health benefits arising from transportation subsidies. Using data from Shanghai, which is comparable to larger cities in Western countries, we take account of the endogeneity of transit subsidy participation and overcome the multicollinearity issue by the unique policy design in China. In Shanghai, elderly persons who are age 70 or older are eligible for free transportation, while those who are under age 70 are not. Using the sudden change in the probability of receiving transportation benefits around age 70, we clearly identify the causal effect of transportation on health status among the elderly by a fuzzy regression discontinuity design (FRD), which is equivalent to the instrumental variable (IV) approach. Moreover, one must take note of the fact that the mandatory retirement age in China is 60 for men and 50 for women ${ }^{2}$, providing a sufficient window of time between retirement age and becoming eligible for transit benefits to ensure that our estimates do not suffer from multicollinearity problems.

Second, our estimates are probably very close to the average treatment effects (ATE) that capture the health impacts of free public transit on the overall aging population. Under the IV framework, different instruments measure different local average treatment effects (LATE) among different subpopulations (Imbens and Angrist, 1994). If treatment effects are heterogeneous across subpopulations, then estimated LATE would not be informative in terms of how the average health status of elderly has been improved by transit subsidies. Economists have started to search for robust instruments that influence larger and more representative subpopulations, which should not be systematically different from their untreated peers (Oreopoulos, 2006; Ebenstein, 2009). In the

\footnotetext{
${ }^{2} 55$ for female cadres
} 
transit subsidy case, self-selected treatments or any application requirements other than age would prevent us from understanding the ATE. Mah and Mitra (2017) shows that lower-income elderly have a higher likelihood of using their free passes in Canada, by which one would be able to capture the LATE among the lower-income group instead of just using the average population. This paper relies on a remarkable natural experiment in Shanghai, where $82.5 \%$ eligible elderly people receive free transit benefits, to estimate the average impacts of transit subsidies on senior citizens' health statuses.

Third, we clearly identify the mechanisms by which public transportation benefits affect the elderly's health status. We examine three possible channels: amount of exercise, food consumption, and health care utilization. According to conventional wisdom, free transit programs may encourage people to use public transit instead of personal vehicles, thus increasing incidental physical activity and even that amount of exercise could potentially improve public health. We argue that the health impact of free transit programs through added exercise will be limited, or at least statistically insignificant. On the contrary, we show that the greater health impacts will be driven by increased food consumption and expanded health care utilization. Free transit programs improve the elderly's access to markets and hospitals. Specifically, households with low food budgets may substitute transportation consumption with more food; and people living close to the hospital (no more than two kilometers) will visit their doctors more frequently and thus spend more on health care.

Our baseline IV results show that free public transportation significantly improves the elderly's health by approximately 10.1 percentage points, while the corresponding OLS indicates 10.8 percentage points. We show that the treatment group of elderly free transit recipients are no different from the control group in terms of gender, schooling, 
number of children, marital status, exercise levels, and pensions around the eligibility cutoff. We have also conducted a battery of robustness checks and placebo tests to determine whether our results are sensitive to functional forms of the forcing variable in FRD, and whether our results are driven by cohort-specific unobserved factors other than transit benefits.

The remainder of this paper organized as follows. Section 2 briefly introduces the institutional background. Section 3 provides the identification strategy. Section 4 describes the dataset and lists the descriptive statistics. The following section presents our baseline results. Section 6 discusses the mechanisms. Section 7 checks the robustness of our results. Section 8 concludes.

\section{Institutional Background}

Shanghai has always been one of the most populous cities in the world, with a permanent population estimated to have been approximately 24.15 million in $2015^{3}$. Senior citizens aged 65 or over account for $19.6 \%$ among the registered population, which is comparable to global cities such as London $\left(21 \%^{4}\right)$, New York City $\left(13.2 \%^{5}\right)$, and Tokyo $\left(23.3 \%^{6}\right)$. In the context of the rapid aging process, Shanghai has enhanced its healthcare insurance system and old-age pension to improve the quality of life of the elderly.

Beginning in 2009, Shanghai has carried out a free ride permits for senior citizens who are at least 70 years old. After applying to the free transit program, eligible citizens obtain a public transit pass that entitles them to unlimited travel by metro and bus

\footnotetext{
${ }^{3}$ Source: Shanghai Municipal Statistics Bureau, 2015

${ }^{4}$ Source: Predicted value during 2011-21 reported by London Councils.

${ }^{5}$ Source: Stringer (2017)

${ }^{6}$ Source: Ministry of Internal Affairs and Communications, Japan, 2015
} 
during off-peak hours. The daily utilization of free bus rides reached 412.6 thousand person-times in 2015, which accounts for $10 \%$ of all bus passenger flow ${ }^{7}$. In 2015 , about 1.8 million senior citizens benefited from the free transportation program.

It is worthwhile to emphasize some unique features of the free transit program in Shanghai. First, age is the only requirement for applying the senior pass, and free public transit is for all senior citizens aged 70 or above. In other global cities, the application requirements sometimes include age and income. For example, in Chicago, although all older adults aged 65 years or older are eligible for a reduced fare permit, the ride free permits are only for those who are enrolled in the Illinois Benefit Access Program (IBAP). The income levels for IBAP eligibility range from $\$ 27,610$ or less for an individual, $\$ 36,635$ for a two-person household, and $\$ 45,657$ for a household of three or more people. In Tokyo, the annual cost of a senior pass is only 1,000 Japanese yen for both non-taxpayers and the low-income population, while it costs 20,510 yen for taxpayers whose annual incomes are over 1.25 million yen.

Second, community committees (Juweihui) help to promote the use of free transit pass in Shanghai. In almost all global cities such as Chicago, London, New York City and Tokyo, the senior pass is based on older people's voluntary application. The elderly may enjoy reduced fare or ride-free permits if and only if they had applied. In such cases, more price-sensitive elderly would positively select themselves into subsidy participation. However, the implementation of a free transit pass is semi-mandatory in Shanghai. The community committees are in charge of promoting laws and policies, family planning, population administration, social welfare, etc. under the guidance of local government. Especially in the case of free transit passes, the committees remind el-

\footnotetext{
${ }^{7}$ Source: Bashi Group Companies, the largest public bus operating company in Shanghai. Before 2009, Bashi, Dazhong, Guanzhong, and Qiangsheng were the four largest. After 2009, they merged to become Bashi Group Companies.
} 
igible elderly persons to apply for and receive the free transit pass through door-to-door visitation.

Third, the mandatory retirement age is 60 for men and 50 for women ${ }^{8}$ in Shanghai, which assures the free transit program is not tainted by other aging policies. The multicollinearity among eligible ages for transit, retirement, and health care benefits makes the impact of transit benefits hard to clearly identify. For instance, in major cities in the United States, people aged 65 years or older are eligible for both transit subsidies and Medicare. It is an almost impossible task to isolate the impact of transit subsidies from others when multiple events happen at the same time. However, the clear policy design in Shanghai offers a good opportunity to estimate the impact of transit subsidies on senior citizens.

\section{Identification Strategy}

We begin with a simple model of the relationship between health status and receiving free transportation subsidies:

$$
\text { Health }_{i}=\alpha_{0}+\alpha_{1} \text { Subsidy }_{i}+\boldsymbol{X}_{\boldsymbol{i}}^{\prime} \alpha_{2}+u_{i}
$$

where Healthy $y_{i}$ indicates health status, Subsidy $y_{i}$ indicates receiving transportation subsidy or not, $\boldsymbol{X}_{\boldsymbol{i}}$ is a vector of individual characteristics.

To account for the potential endogeneity of OLS, we estimate the effect of trans-

\footnotetext{
${ }^{8} 55$ for female cadres
} 
portation subsidy on health status using a fuzzy regression discontinuity design.

$$
\begin{aligned}
\text { Health }_{i} & =\beta_{0}+\beta_{1} \text { Subsidy }_{i}+f\left(\text { Age }_{i}\right)+\boldsymbol{X}_{\boldsymbol{i}}^{\prime} \beta_{2}+\epsilon_{i} \\
\text { Subsidy }_{i} & =\gamma_{0}+\gamma_{1} \mathbb{1}\left[\text { Age }_{i} \geq 70\right]+f\left(\text { Age }_{i}\right)+\boldsymbol{X}_{\boldsymbol{i}}^{\prime} \gamma_{2}+\varepsilon_{i}
\end{aligned}
$$

where the binary instrument $\mathbb{1}\left[A g e_{i} \geq 70\right]$ indicates whether one's age is greater than or equal to age $70, f\left(A g e_{i}\right)$ is an unknown function of age. As Gelman and Imbens (2017) shows that using high-degree polynomials of the running variable in regression discontinuity design could lead to noisy estimates, sensitivity to the degree of the polynomial, and poor coverage confidence intervals, we assume a quadratic form of age to approximate $f\left(A g e_{i}\right)$ as our baseline model. Local linear estimates would be shown in the section of robustness checks.

\section{Data}

Our data source is the 2015 Chinese Living Conditions Survey for Rural and Urban Aged Population ${ }^{9}$ (hereinafter abbreviated as CLCS), which is designed to collect information on demographics, economic and health status, living conditions, social inclusion, routine activities, and social welfare among the elderly who are at least 60 years old. It is the largest and most representative survey for the elderly population in the history of China, covering approximately 224 thousand individuals from 466 counties in 31 provinces. In this study, we use the Shanghai sub-sample ${ }^{10}$ that consists of 4,301 senior citizens in the most modern city in China, which is comparable to other global cities with respect to social security and welfare.

\footnotetext{
${ }^{9}$ There is no official English name for this data now. The Chinese name is Zhongguo Chengxiang Laonianren Shenghuozhuangkuang Chouyangdiaocha. see http://dscdc.cncaprc.gov.cn/

${ }^{10}$ To our knowledge, the national sample is still not accessible for academic use. Our data was provided independently by the Shanghai Research Center on Aging.
} 
The CLCS data has three unique features. First, this survey includes information on both self-reported health status and transit subsidy participation, which are the dependent and the key independent variables in estimating the health impact of free transportation. The respondents were directly asked whether or not they are receiving reduced fare or free ride permits benefits. Previous studies have either indirectly measured health by physical activities (Coronini-Cronberg et al., 2012) and obesity (Webb et al., 2011), or treatment status by policy eligibility (Edwards et al., 2013). Second, our data provides detailed information on year and month of birth, which enables us to perform an RD design to estimate the causal effect of free transit on health status among senior citizens. In contrast, previous studies did not pay attention to endogenous subsidy participation. Third, rich information on routine activities and expenditures helps us to test the mechanisms through which free transit may improve senior citizens' health status.

To evaluate the health impact of free transportation on senior citizens, we restricted the sample as follows: (1) we dropped observations with missing values in health status, receiving free transit subsidy, and birth information, the latter being necessary to identify and evaluate age-based policies; (2) we construct a vector of covariates including gender, schooling, marital status, number of children, exercise frequency, and pensions, and we also drop observations in these covariates; (3) we only kept observations for elderly between the ages of 65 and 75, with a five-year bandwidth relative to age 70, assuring that neither the control nor the treatment group was affected by retirement or aging policies other than the free transit benefit. This procedure left us with a final sample containing 1,351 observations.

Table 1 shows descriptive statistics of all variables used in our baseline model. In 
the overall sample (Column 1), the average age is 69.29 , and $47.4 \%$ of the elderly are men. Most of the senior citizens were married and living with their spouses, and the average number of children was $1.65 ; 27.8 \%$ of them do not do any exercise, and the average pension was 2,937 Chinese yuan (USD 484) on a monthly basis. Column 2 and Column 3 show the statistics for 65-70 and 70-75 age groups, respectively. Compared to those who are not eligible for the transit benefit, those who are at least 70 years old have a higher likelihood of receiving a transit subsidy. Nevertheless, their health status does not differ. To test the difference between the two groups, we show the results of the t-statistic in Column 4. For the covariates, only differences in marital status and the number of children are observed between the two age groups, but nothing in terms of gender, schooling, exercise frequency, or pensions.

\section{$5 \quad$ Results}

In this section, we discuss the estimates of FRD design, which were designed to analyze the policy impact of transportation subsidies on health status among the elderly. We first discuss the first-stage estimates of subsidy eligibility upon receiving those benefits, and then we show the results of baseline FRD estimation. In our baseline estimation, models are fitted by the global polynomial method in a quadratic form. In all regressions, we use standard errors clustered at the district level for inference. Among four specifications, the estimates with full controls are our preferred results, and these estimates are the focus of the discussion in the following subsections. In the final subsection, we discuss the validity of our FRD estimates. 


\subsection{First Stage}

Figure 1 graphs the probability of receiving transportation subsidy against age in decimal years. The hollow circles indicate means of observed probability of receiving subsidy within each age cell, which are weighted by the number of observations in each corresponding cell. The red curve shows a quadratic fit for who are younger than 70 , while the blue curve is fitted for those who are greater than or equal to 70 . Figure 1 also shows clear discontinuous changes in the probability of receiving subsidy around age 70. Visually, the probability of receiving subsidy is approximately 80 percentage points higher among the elderly who had just turned 70, compared to their younger peers who were still 69 years old.

Table 2 reports the first stage of IV estimates corresponding to Figure 1. Columns 1 to 4 use four specifications of covariates. We control for covariates of basic demographic information, marital status, amount of exercise, and pension. Column 4 sets full controls for our preferred results. According to Column 4, the elderly who were just on the right tail of eligibility cutoff are more likely to receive transportation subsidies by 76.3 percentage points, which is highly robust across specifications. The age-based transportation subsidy is probably executed strictly within a few self-selection issues. The F-statistics of excluded instruments are consistently over 400, indicating that weak instruments might not be a concern in this paper. Smoothness tests on covariates will be discussed later.

\subsection{Baseline Results}

Figure 2 graphically shows the health status around the eligibility cutoff at age 70. Like in Figure 1, each hollow circle indicates a weighted mean of observed health 
status within each age cell. Red and blue curves fit the data in a quadratic form, while corresponding dashed lines use a local linear form. Figure 2 shows consistently positive health effects regardless of the fitting methods used. Health status is not monotonically decreasing in age. Surprisingly, the elderly over age 70 are in better health than their younger peers.

Table 3 presents results of our baseline FRD estimation, which is equivalent to a conventional IV approach. IV estimates are displayed in Column 2 to 5 , while OLS is also listed in Column 1 for comparison. The positive health effects are highly stable across different specifications, even after we had controlled for marital status, amount of exercise, and pension - other elements that could be a determinant of health status. According to Column 5, receiving transportation subsidies improved the elderly's health status by 10.1 percentage points.

Generally, IV estimation captures the effect of treatment on compliers rather than those on the average population. The average effect among compliers is also called local average treatment effect (LATE). If compliers select themselves into treatment, then IV estimates should be interpreted cautiously since self-selected compliers could be different from non-compliers through observable characteristics. In the context of transportation subsidies, if persons with low budget constraints positively select themselves into subsidy participation, then the LATE only presents the health effect among this subpopulation. In our research, the LATE is the effect of receiving transportation subsidies on health status among the eligible elderly, who get the benefits because they are at least age 70 , but who would not get the benefits otherwise.

It is worthwhile emphasizing that our estimated LATE are very close to the population average. For instance, the IV estimate with full controls (Table 3, Column 5) 
indicate a positive health effect of 10.1 percentage points, while the corresponding OLS estimate yields 10.8 percentage points. The difference between OLS and IV is only 0.7. The particularly strong instrument, as shown in Table 2, indicates that age is the dominant factor for subsidy participation rather than any other observed factors. In this paper, the treatment group is probably homogenous with the control group in covariates.

\subsection{Smoothness Tests}

According to Column 4 in Table 1, those who are at least age 70 are not different from their younger peers in covariates of gender, schooling, amount of exercise, and pension. However, slight differences were noted in numbers of children and marital status. If these differences occurred around the eligibility cutoff point, then our FRD estimates would be invalid and misleading. To directly test this possibility, we test whether these covariates were correlated to some discontinuity in the probability of receiving transportation benefits.

Figure 3 shows that no clear jumps are observed in each covariate, which is robust to both quadratic and linear fits. In Figure 3, we graph each covariate against age in six panels. As marital status and exercising are category variables, we use the probability of being widowed and exercising instead for consciousness sake. In China, variations in marital status among the elderly basically come from widowhood, only $1 \%$ and $2 \%$ persons are never married and divorced in our final sample (see Table 1). Using a binary variable to measure marital status might not be problematic.

Table 4 reports the estimated coefficients corresponding to Figure 3, indicating no statistical correlation between the cutoff and each covariate. In each column, the covariate itself is the dependent variable and excluded from the vector of covariates. Similar with Figure 3, the eligibility cutoff is not correlated to gender, schooling, number 
of children, widowhood, undertaking exercise, and pension, indicating these covariates are smooth at age 70 .

\section{Mechanisms}

Our baseline results in Table 3 suggest that those elderly who receive free transit benefits are substantially healthier than those who do not. In this section, we propose three possible channels through which transportation may consequently affect senior citizens' health status, which are (1) exercise and routine activities, (2) health care utilization, and (3) improved food consumption. We use the same FRD estimation strategy as shown in Equation 2 and include a full set of covariates for causal inference. Different dependent variables and subsamples are used to investigate how the elderly respond to the free-transit benefit.

First, we argue that the health impact of free transit through exercise and routine activities should be very limited, at least statistically insignificant. In Column 5 of Table 4, as well as in Panel $\mathrm{E}$ of Figure 3, we have already shown that free public transportation does not have any effect on the elderly's exercise preferences. To test whether receiving transit benefits may affect older people's health through incidental activities, we regressed 12 kinds of routine activities against subsidy-receiving status. In Table 5, we show that free transit is not related to either indoor or outdoor activities.

We then test whether the elderly's consumption of food and medical care are impacted by the free transportation program. Table 6 shows the impact of free transit pass on food and medical care expenditures, in Panel B and Panel C, respectively. Panel A shows the estimates on transit expenditures by way of comparison. We construct subsamples according to food budget and distance from the hospital to investigate the 
heterogeneous effects. Panel $\mathrm{B}$ and Panel $\mathrm{C}$ of Table 6 offer some evidence that the health impact resulting from the free transportation program could be through attaining a better diet via increased food intake among households with smaller food budgets, and increased in medical care expenditures among those who lived close to the hospital or physicians' offices.

\section{Robustness Checks}

\subsection{Selection on Bandwidth}

So far, we presented our results based on the global polynomial method. Our baseline model assumes a quadratic form of running variable. To test whether our baseline results are sensitive to different methods, we also present a nonparametric means-a local linear regression-to estimate the fuzzy regression discontinuity equation.

$$
\begin{aligned}
\text { Health }_{i} & =\theta_{0}+\theta_{1} \text { Subsidy }_{i}+\theta_{2} \widetilde{A g e}_{i}+\theta_{3} \mathbb{1}\left[A g e_{i} \geq 70\right] * \widetilde{A g e_{i}}+\boldsymbol{X}_{\boldsymbol{i}}^{\prime} \theta_{4}+\phi_{i} \\
\text { Subsidy }_{i} & =\rho_{0}+\rho_{1} \mathbb{1}\left[\text { Age }_{i} \geq 70\right]+\rho_{2} \widetilde{A g e_{i}}+\rho_{3} \mathbb{1}\left[\text { Age }_{i} \geq 70\right] * \widetilde{A g e_{i}}+\boldsymbol{X}_{\boldsymbol{i}}^{\prime} \rho_{4}+\psi_{i}
\end{aligned}
$$

where $\widetilde{A g e_{i}}=A g e_{i}-A g e_{0}$, and $A g e_{0}$ is 70. In these local linear regressions, we use 1-year, 2-year, 3-year, and 4-year banding.

Results of local linear regressions with different bandwidths are shown in Table 7. Regardless of where bands fall relative to the cutoff, consistent positive health effects are observed (columns 2, 3, 4, and 5), which are similar to our baseline model assuming a quadratic form of age. 


\subsection{Placebo Tests}

In this subsection, we use four placebo treatments to test the robustness of the fuzzy RD estimates. These placebo treatments are two-years prior, one-year prior, oneyear posterior, two-years posterior to the actual treatment received. These placebo treatments should not have any effect on health. If we find an impact from a placebo treatment, the real treatment-based results might be driven by other unobserved factors rather than the transportation benefit. Congruently, the following reduced-form equation is estimated,

$$
\text { Health }_{i}=\delta_{0}+\delta_{1} \mathbb{1}\left[\text { Age }_{i} \geq 70 \pm p\right]+f\left(\text { Age }_{i}\right)+\boldsymbol{X}_{\boldsymbol{i}}^{\prime} \delta_{2}+v_{i}
$$

where $p$ denotes the placebo treatment relative to the real treatment of age 70 . The reduced form estimates of placebo treatments are displayed in Table 8, and the estimate of real treatment is also listed by way of comparison. Again, none of these placebo treatments had any significant effect on health.

\section{Concluding Remarks}

This paper estimates the causal effect of transportation benefits on health status among the elderly. Using a unique survey with detailed information on month of birth, we exploit a fuzzy regression discontinuity design to investigate the difference in health status between who are below or above age 65 . We offer clear evidence that transportation subsidies improve senior citizens' health by approximately 10\%. Our results are robust to different specifications and have rich policy implications for the aging society and government expenditure on elder care. 


\section{Compliance with Ethical Standards:}

Conflict of Interest: This study is conducted as a part of the project "Economic Analysis of the Development of the Nursing Care Industry in China and Japan" undertaken at the Research Institute of Economy, Trade and Industry(RIETI). 


\section{References}

Anderson, M. L. (2014). Subways, Strikes, and Slowdowns: The Impacts of Public Transit on Traffic Congestion. American Economic Review, 104(9):2763-2796.

Bell, J. and Cohen, L. (2009). The Transportation Prescription: Bold New Ideas for Healthy, Equitable Transportation Reform in America. PolicyLink and Prevention Institute, Oakland, CA.

Bueno, P. C., Gomez, J., Peters, J. R., and Vassallo, J. M. (2017). Understanding the effects of transit benefits on employees' travel behavior: Evidence from the New YorkNew Jersey region. Transportation Research Part A: Policy and Practice, 99:1-13.

Coronini-Cronberg, S., Millett, C., Laverty, A. A., and Webb, E. (2012). The impact of a free older persons' bus pass on active travel and regular walking in England. American Journal of Public Health, 102(11):2141-2148.

Craig, P., Cooper, C., Gunnell, D., Haw, S., Lawson, K., Macintyre, S., Ogilvie, D., Petticrew, M., Reeves, B., Sutton, M., and Thompson, S. (2012). Using natural experiments to evaluate population health interventions: new Medical Research Council guidance. Journal of Epidemiology and Community Health, 66(12):1182-1186.

Ebenstein, A. (2009). When is the Local Average Treatment Close to the Average? Evidence from Fertility and Labor Supply. Journal of human Resources, 44(4):955975.

Edwards, P., Steinbach, R., Green, J., Petticrew, M., Goodman, A., Jones, A., Roberts, H., Kelly, C., Nellthorp, J., and Wilkinson, P. (2013). Health impacts of free bus 
travel for young people: evaluation of a natural experiment in London. Journal of Epidemiology and Community Health, 67(8):641-647.

Gelman, A. and Imbens, G. (2017). Why high-order polynomials should not be used in regression discontinuity designs. Journal of Business $\&$ Economic Statistics.

Green, J., Jones, A., and Roberts, H. (2014). More than A to B: the role of free bus travel for the mobility and wellbeing of older citizens in London. Ageing and society, $34(3): 472-494$.

Imbens, G. W. and Angrist, J. D. (1994). Identification and estimation of local average treatment effects. Econometrica, 62(2):467-475.

Mah, S. and Mitra, R. (2017). The effects of a free bus program on older adults travel behaviour: A case study of a Canadian suburban municipality. Case Studies on Transport Policy, 5(3):460-466.

Oreopoulos, P. (2006). Estimating Average and Local Average Treatment Effects of Education when Compulsory Schooling Laws Really Matter. American Economic Review, 96(1):152-175.

Parry, I. W. H. and Small, K. A. (2009). Should Urban Transit Subsidies Be Reduced? American Economic Review, 99(3):700-724.

Stringer, S. M. (2017). Aging with Dignity: A Blueprint for Serving NYC's Growing Senior Population. https://comptroller.nyc.gov/reports/aging-with-dignity-a-blueprintfor-serving-nycs-growing-senior-population/.

Webb, E., Netuveli, G., and Millett, C. (2011). Free bus passes, use of public transport 
and obesity among older people in England. Journal of Epidemiology and Community Health, 66(2):176-180. 
Table 1: Descriptive Statistics

\begin{tabular}{|c|c|c|c|c|}
\hline \multirow[b]{2}{*}{ VARIABLES } & \multirow[b]{2}{*}{$\begin{array}{c}(1) \\
\text { Overall }\end{array}$} & \multicolumn{3}{|c|}{ By Age } \\
\hline & & $\begin{array}{c}(2) \\
{[70,75]}\end{array}$ & $\begin{array}{c}(3) \\
{[65,70)}\end{array}$ & $\begin{array}{c}(4) \\
\text { Difference }\end{array}$ \\
\hline Age & $\begin{array}{l}69.285 \\
(2.838)\end{array}$ & $\begin{array}{l}72.378 \\
(1.454)\end{array}$ & $\begin{array}{l}67.343 \\
(1.416)\end{array}$ & $\begin{array}{l}5.035 * * * \\
(0.080)\end{array}$ \\
\hline Receiving subsidy & $\begin{array}{c}0.329 \\
(0.470)\end{array}$ & $\begin{array}{c}0.825 \\
(0.380)\end{array}$ & $\begin{array}{c}0.017 \\
(0.129)\end{array}$ & $\begin{array}{l}0.808^{* * *} \\
(0.014)\end{array}$ \\
\hline Health & $\begin{array}{c}0.869 \\
(0.338)\end{array}$ & $\begin{array}{c}0.850 \\
(0.357)\end{array}$ & $\begin{array}{c}0.881 \\
(0.324)\end{array}$ & $\begin{array}{l}-0.030 \\
(0.019)\end{array}$ \\
\hline Male & $\begin{array}{c}0.474 \\
(0.500)\end{array}$ & $\begin{array}{c}0.491 \\
(0.500)\end{array}$ & $\begin{array}{c}0.464 \\
(0.499)\end{array}$ & $\begin{array}{c}0.028 \\
(0.028)\end{array}$ \\
\hline Schooling & $\begin{array}{c}9.511 \\
(3.819)\end{array}$ & $\begin{array}{c}9.480 \\
(4.296)\end{array}$ & $\begin{array}{c}9.531 \\
(3.489)\end{array}$ & $\begin{array}{l}-0.051 \\
(0.214)\end{array}$ \\
\hline Number of children & $\begin{array}{c}1.652 \\
(0.830)\end{array}$ & $\begin{array}{c}1.973 \\
(0.964)\end{array}$ & $\begin{array}{c}1.451 \\
(0.659)\end{array}$ & $\begin{array}{l}0.523^{* * *} \\
(0.044)\end{array}$ \\
\hline $\begin{array}{l}\text { Marital Status } \\
\text { Married with spouse }\end{array}$ & $\begin{array}{c}0.847 \\
(0.360)\end{array}$ & $\begin{array}{c}0.812 \\
(0.391)\end{array}$ & $\begin{array}{c}0.869 \\
(0.338)\end{array}$ & $\begin{array}{l}-0.057^{* *} \\
(0.020)\end{array}$ \\
\hline Widowed & $\begin{array}{c}0.123 \\
(0.328)\end{array}$ & $\begin{array}{c}0.173 \\
(0.378)\end{array}$ & $\begin{array}{c}0.092 \\
(0.289)\end{array}$ & $\begin{array}{l}0.081^{* * *} \\
(0.018)\end{array}$ \\
\hline Divorced & $\begin{array}{c}0.020 \\
(0.140)\end{array}$ & $\begin{array}{c}0.013 \\
(0.115)\end{array}$ & $\begin{array}{c}0.024 \\
(0.153)\end{array}$ & $\begin{array}{l}-0.011 \\
(0.008)\end{array}$ \\
\hline Never married & $\begin{array}{c}0.010 \\
(0.101)\end{array}$ & $\begin{array}{c}0.002 \\
(0.044)\end{array}$ & $\begin{array}{l}0.016 \\
(0.124)\end{array}$ & $\begin{array}{l}-0.014^{*} \\
(0.006)\end{array}$ \\
\hline Exercise & & & & \\
\hline No exercise & $\begin{array}{c}0.278 \\
(0.448)\end{array}$ & $\begin{array}{c}0.296 \\
(0.457)\end{array}$ & $\begin{array}{c}0.267 \\
(0.443)\end{array}$ & $\begin{array}{c}0.028 \\
(0.025)\end{array}$ \\
\hline No more than once/wk & $\begin{array}{c}0.049 \\
(0.216)\end{array}$ & $\begin{array}{c}0.054 \\
(0.226)\end{array}$ & $\begin{array}{c}0.046 \\
(0.209)\end{array}$ & $\begin{array}{c}0.008 \\
(0.012)\end{array}$ \\
\hline 1-2 times/wk & $\begin{array}{c}0.171 \\
(0.377)\end{array}$ & $\begin{array}{c}0.163 \\
(0.370)\end{array}$ & $\begin{array}{c}0.176 \\
(0.381)\end{array}$ & $\begin{array}{l}-0.013 \\
(0.021)\end{array}$ \\
\hline 3-5 times/wk & $\begin{array}{c}0.195 \\
(0.397)\end{array}$ & $\begin{array}{c}0.186 \\
(0.390)\end{array}$ & $\begin{array}{c}0.201 \\
(0.401)\end{array}$ & $\begin{array}{l}-0.015 \\
(0.022)\end{array}$ \\
\hline More than 6 times/wk & $\begin{array}{c}0.306 \\
(0.461)\end{array}$ & $\begin{array}{c}0.301 \\
(0.459)\end{array}$ & $\begin{array}{c}0.310 \\
(0.463)\end{array}$ & $\begin{array}{l}-0.008 \\
(0.026)\end{array}$ \\
\hline Pension/1000 & $\begin{array}{c}2.937 \\
(1.402)\end{array}$ & $\begin{array}{c}3.001 \\
(1.505)\end{array}$ & $\begin{array}{c}2.897 \\
(1.333)\end{array}$ & $\begin{array}{c}0.104 \\
(0.078)\end{array}$ \\
\hline Observations & 1,351 & 521 & 830 & 1,351 \\
\hline
\end{tabular}

Notes: Standard deviations in parentheses. Column 4 is the raw difference between the two age groups. ${ }^{* * *} \mathrm{p}<0.01,{ }^{* *} \mathrm{p}<0.05,{ }^{*} \mathrm{p}<0.1$ 
Figure 1: First Stage

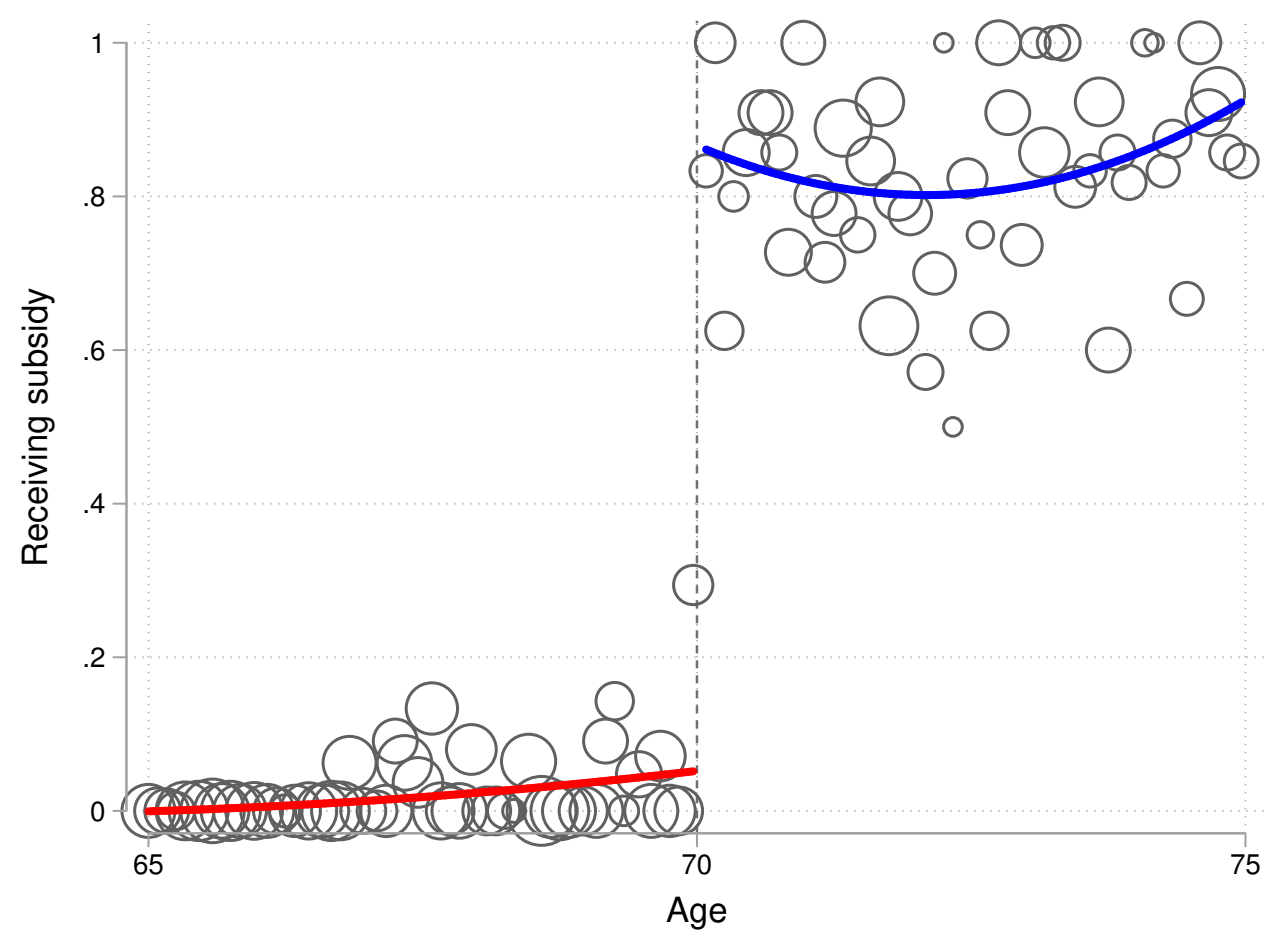

Notes: Quadratic polynomial fit is used. Each data point is weighted by number of observations within each age cell. 
Table 2: First Stage

\begin{tabular}{lcccc}
\hline & \multicolumn{4}{c}{ Dependent Variable: Receiving Subsidy } \\
\cline { 2 - 5 } & $(1)$ & $(2)$ & $(3)$ & $(4)$ \\
\hline \multirow{2}{*}{ Age $\geq 70$} & $0.761^{* * *}$ & $0.760^{* * *}$ & $0.762^{* * *}$ & $0.763^{* * *}$ \\
& $(0.034)$ & $(0.036)$ & $(0.037)$ & $(0.038)$ \\
& & & & \\
Basic controls & Yes & Yes & Yes & Yes \\
Marital status & No & Yes & Yes & Yes \\
Exercise & No & No & Yes & Yes \\
Pension & No & No & No & Yes \\
Observations & 1,351 & 1,351 & 1,351 & 1,351 \\
R-squared & 0.705 & 0.707 & 0.710 & 0.711 \\
F-statistic & 486.93 & 456.94 & 434.44 & 411.42 \\
\hline
\end{tabular}

Notes: Standard errors are clustered at district level. Basic controls include age, age squared, male dummy, schooling, and number of children. *** $\mathrm{p}<0.01$, $\mathrm{p}<0.05,{ }^{*} \mathrm{p}<0.1$ 
Figure 2: Health Status

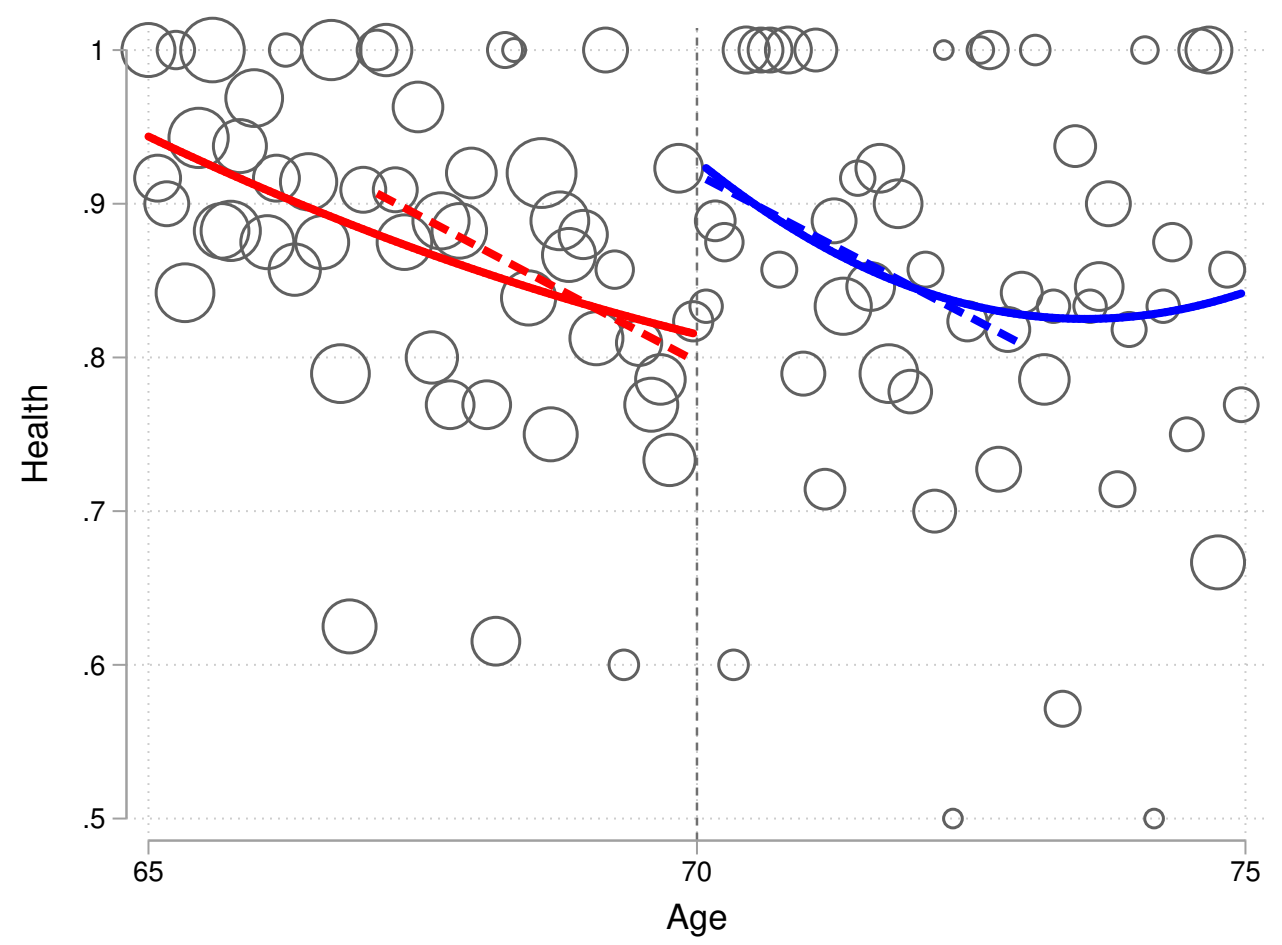

Notes: Solid curves globally fit the data in a quadratic form, while dashed lines use a local linear form. Each data point is weighted by the number of observations within each age cell. 
Table 3: Estimated Coefficients on Health Status

\begin{tabular}{lccccc}
\hline & & \multicolumn{5}{c}{ Quadratic Form } \\
\cline { 3 - 6 } VARIABLES & $(1)$ & $(2)$ & $(3)$ & $(4)$ & $(5)$ \\
& OLS & IV & IV & IV & IV \\
\hline \multirow{2}{*}{ Receiving subsidy } & $0.108^{* * *}$ & $0.104^{* *}$ & $0.101^{* *}$ & $0.102^{* * *}$ & $0.101^{* *}$ \\
& $(0.026)$ & $(0.042)$ & $(0.041)$ & $(0.040)$ & $(0.040)$ \\
Basic controls & Yes & Yes & Yes & Yes & Yes \\
Marital status & Yes & No & Yes & Yes & Yes \\
Exercise & Yes & No & No & Yes & Yes \\
Pension & Yes & No & No & No & Yes \\
Observations & 1,351 & 1,351 & 1,351 & 1,351 & 1,351 \\
R-squared & 0.049 & 0.026 & 0.027 & 0.049 & 0.049 \\
\hline
\end{tabular}

Notes: Standard errors are clustered at district level. Basic controls include age, age squared, male dummy, schooling, and number of children. *** $\mathrm{p}<0.01, * * \mathrm{p}<0.05, * \mathrm{p}<0.1$ 
Figure 3: Smoothness Checks

Panel A: Male

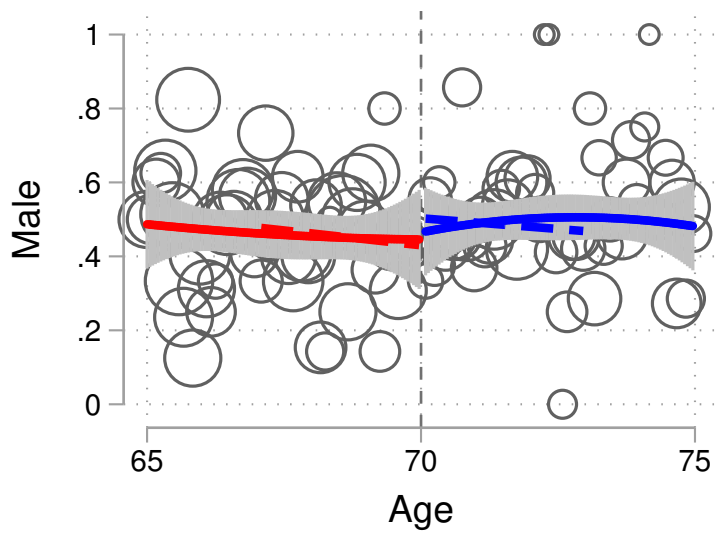

Panel C: \#Children
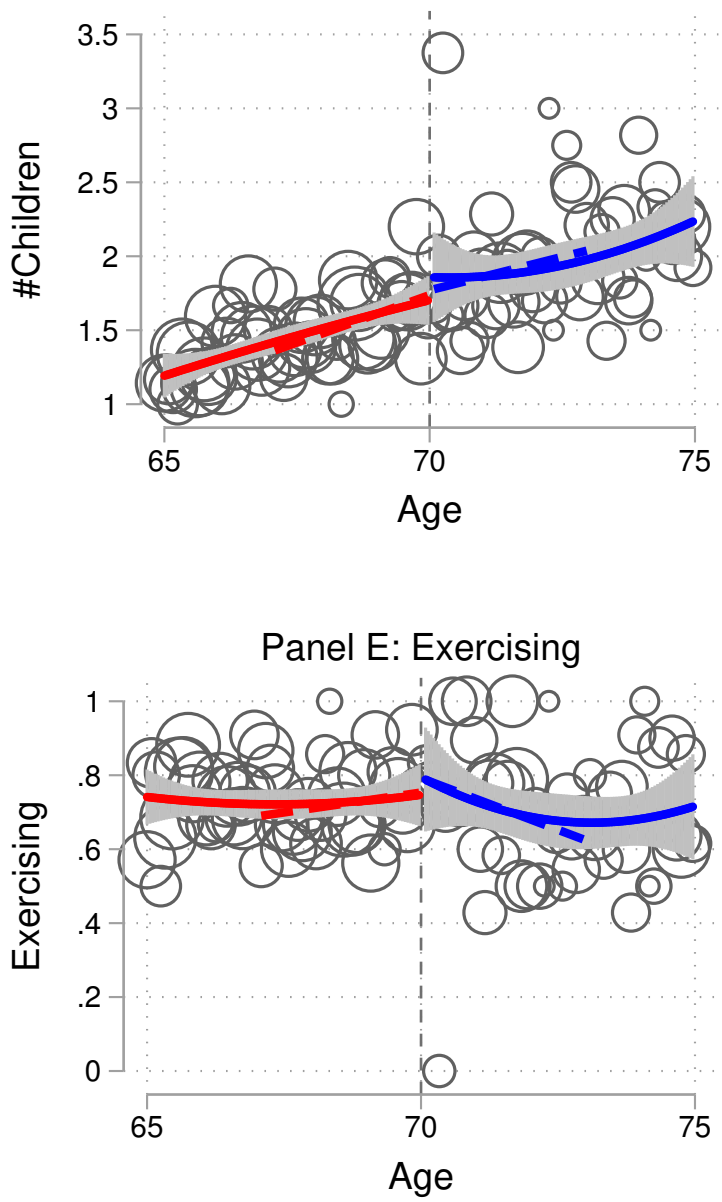

Panel B: Schooling

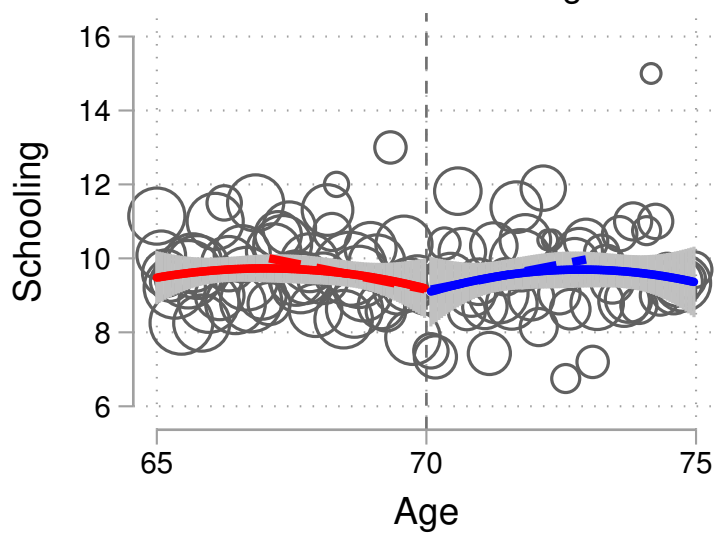

Panel D: Widowed
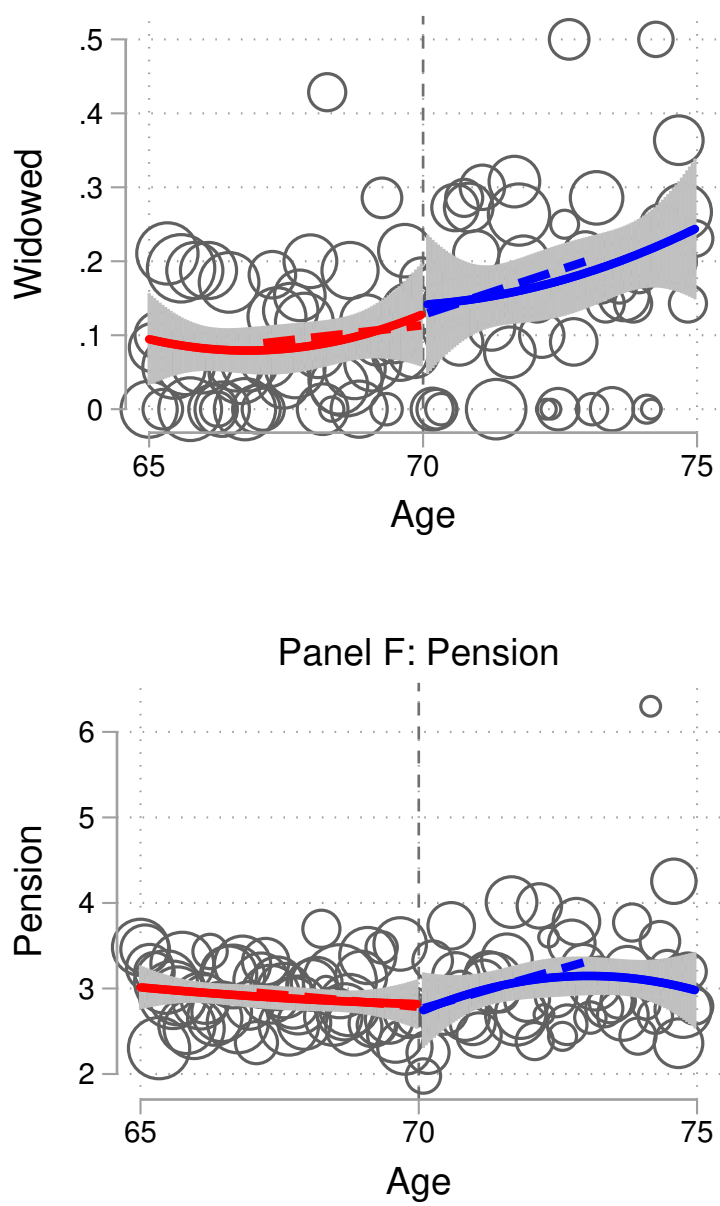

Notes: Solid curves globally fit the data in a quadratic form, while dashed lines use a local linear form. Confidence intervals are attached around the quadratic fit for each panel. Each data point is weighted by number of observations within each age cell. 
Table 4: Smoothness Tests on Covariates

\begin{tabular}{lcccccc}
\hline & \multicolumn{5}{c}{ Quadratic Form } \\
\cline { 2 - 7 } VARIABLES & $\begin{array}{c}(1) \\
\text { Male }\end{array}$ & $\begin{array}{c}(2) \\
\text { Schooling }\end{array}$ & $\begin{array}{c}(3) \\
\text { \#Children }\end{array}$ & $\begin{array}{c}(4) \\
\text { Widowed }\end{array}$ & $\begin{array}{c}(5) \\
\text { Exercising }\end{array}$ & $\begin{array}{c}(6) \\
\text { Pension }\end{array}$ \\
\hline Age $\geq 70$ & & & & & & \\
& 0.028 & -0.267 & 0.044 & 0.016 & -0.008 & 0.101 \\
& $(0.048)$ & $(0.427)$ & $(0.086)$ & $(0.054)$ & $(0.052)$ & $(0.150)$ \\
Observations & & & & & & \\
R-squared & 1,351 & 1,351 & 1,351 & 1,351 & 1,351 & 1,351 \\
Male & 0.075 & 0.413 & 0.345 & 0.056 & 0.048 & 0.414 \\
Schooling & No & Yes & Yes & Yes & Yes & Yes \\
Number of children & Yes & No & Yes & Yes & Yes & Yes \\
Marital status & Yes & Yes & No & Yes & Yes & Yes \\
Exercise & Yes & Yes & Yes & No & Yes & Yes \\
Pension & Yes & Yes & Yes & Yes & No & Yes \\
\hline
\end{tabular}

Notes: Standard errors are clustered at district level. ${ }^{* * *} \mathrm{p}<0.01,{ }^{* *} \mathrm{p}<0.05,{ }^{*} \mathrm{p}<0.1$ 
Table 5: Routine Activities

\begin{tabular}{|c|c|c|c|c|c|c|}
\hline \multirow[b]{2}{*}{ VARIABLES } & \multicolumn{6}{|c|}{ Quadratic form } \\
\hline & $\begin{array}{c}(1) \\
\text { TV/ } \\
\text { Radio }\end{array}$ & $\begin{array}{c}(2) \\
\text { Books/ } \\
\text { Newspapers }\end{array}$ & $\begin{array}{c}(3) \\
\text { Cinema-/ } \\
\text { Theater-going }\end{array}$ & $\begin{array}{c}\quad(4) \\
\text { Walks/ } \\
\text { Jogging }\end{array}$ & $\begin{array}{c}(5) \\
\text { Tai-chi/ } \\
\text { Stretching }\end{array}$ & $\begin{array}{c}(6) \\
\text { Dancing }\end{array}$ \\
\hline Receiving subsidy & $\begin{array}{l}-0.025 \\
(0.023)\end{array}$ & $\begin{array}{l}-0.076 \\
(0.061)\end{array}$ & $\begin{array}{l}-0.026 \\
(0.039)\end{array}$ & $\begin{array}{l}-0.054 \\
(0.058)\end{array}$ & $\begin{array}{c}0.021 \\
(0.038)\end{array}$ & $\begin{array}{c}0.039 \\
(0.035)\end{array}$ \\
\hline Mean of control group & 0.983 & 0.588 & 0.094 & 0.694 & 0.093 & 0.083 \\
\hline \multirow[t]{2}{*}{ R-squared } & $\begin{array}{l}1.351 \\
0.009\end{array}$ & $\begin{array}{l}1.351 \\
0.292\end{array}$ & $\begin{array}{l}1.351 \\
0.039\end{array}$ & $\begin{array}{l}1.351 \\
0.251\end{array}$ & $\begin{array}{l}1.351 \\
0.078\end{array}$ & $\begin{array}{l}1.351 \\
0.073\end{array}$ \\
\hline & \multicolumn{6}{|c|}{ Quadratic form } \\
\hline VARIABLES & $\begin{array}{c}(7) \\
\text { Gateball/ } \\
\text { Table tennis/ } \\
\text { Badminton }\end{array}$ & $\begin{array}{c}(8) \\
\text { Mahjong/ } \\
\text { Cards/ } \\
\text { Chess }\end{array}$ & $\begin{array}{c}(9) \\
\text { Gardening }\end{array}$ & $\begin{array}{l}(10) \\
\text { Pets }\end{array}$ & $\begin{array}{c}(11) \\
\text { Fishing/Paintings/ } \\
\text { Photography/ } \\
\text { Collection }\end{array}$ & $\begin{array}{c}(12) \\
\text { Others }\end{array}$ \\
\hline Receiving subsidy & $\begin{array}{c}0.003 \\
(0.019)\end{array}$ & $\begin{array}{c}0.006 \\
(0.054)\end{array}$ & $\begin{array}{l}-0.020 \\
(0.064)\end{array}$ & $\begin{array}{c}0.056 \\
(0.037)\end{array}$ & $\begin{array}{c}0.002 \\
(0.031)\end{array}$ & $\begin{array}{c}0.004 \\
(0.016)\end{array}$ \\
\hline Mean of control group & 0.033 & 0.154 & 0.308 & 0.070 & 0.054 & 0.011 \\
\hline Observations & 1.351 & 1.351 & 1.351 & 1.351 & 1.351 & 1.351 \\
\hline R-squared & 0.033 & 0.037 & 0.111 & 0.010 & 0.060 & 0.008 \\
\hline
\end{tabular}

Notes: Standard errors are clustered at district level. All specifications include basic controls, marital status, amount of exercise, and pension. ${ }^{* * *} \mathrm{p}<0.01,{ }^{*} \mathrm{p}<0.05,{ }^{*} \mathrm{p}<0.1$ 
Table 6: Potential Mechanisms: Consumptions on Transit, Food, and Medical Care

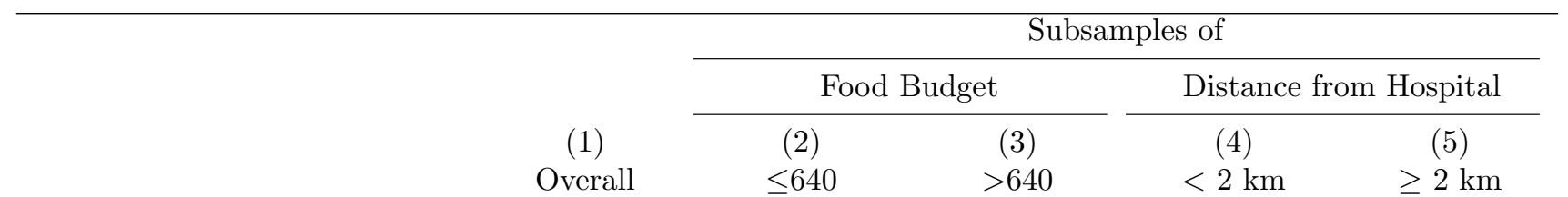

Overall

$\leq 640$

$>640$

$<2 \mathrm{~km}$

$\geq 2 \mathrm{~km}$

Panel A: Transit

Receiving subsidy

Mean of control group

$\begin{array}{cclcc}-56.048^{* * *} & -42.783^{* * *} & -58.554^{* * *} & -34.775^{* * *} & -100.261^{* *} \\ (19.224) & (7.242) & (20.664) & (13.019) & (44.918) \\ 96.508 & 39.787 & 103.321 & 86.466 & 113.885\end{array}$

\section{Panel B: Food}

Receiving subsidy

$\begin{array}{lll}-220.359 & 99.259^{* *} & -248.867 \\ (149.891) & (39.700) & (154.534) \\ 2342.024 & 402.247 & 2575.007\end{array}$

Mean of control group

2342.024

402.247

2575.007

Panel C: Medical care/100

Receiving subsidy

\begin{tabular}{|c|c|c|c|c|}
\hline 6.838 & & & $50.199^{* *}$ & -104.757 \\
\hline$(22.528)$ & & & $(23.166)$ & $(68.502)$ \\
\hline 73.989 & - & - & 46.462 & 121.618 \\
\hline
\end{tabular}

Observations

1,351

153

1,198

873

478

Notes: Standard errors are clustered at district level. All specifications include basic controls, marital status, amount of exercise, and pension. Each coefficient denotes a separate regression. Expenditure on medical care is divided by $100 .{ }^{* * *} \mathrm{p}<0.01,{ }^{* *} \mathrm{p}<0.05,{ }^{*} \mathrm{p}<0.1$ 
Table 7: Choice of Bandwidths

\begin{tabular}{lccccc}
\hline & & \multicolumn{3}{c}{ Local Linear Regression } \\
\cline { 3 - 6 } & $\begin{array}{c}(1) \\
\text { Quadratic }\end{array}$ & \pm 4 Sample & \pm 3 Sample & \pm 2 Sample & \pm 1 Sample \\
\hline \multirow{2}{*}{ Receiving subsidy } & $0.101^{* *}$ & $0.107^{* *}$ & $0.131^{* *}$ & $0.130^{*}$ & $0.178^{*}$ \\
& $(0.040)$ & $(0.043)$ & $(0.057)$ & $(0.076)$ & $(0.107)$ \\
Observations & 1,351 & 1,080 & & & \\
R-squared & 0.049 & 0.041 & 0.042 & 0.050 & 0.099 \\
\hline
\end{tabular}

Notes: Standard errors are clustered at the district level. All specifications include basic controls, marital status, amount of exercise, and pension. ${ }^{* * *} \mathrm{p}<0.01,{ }^{* *} \mathrm{p}<0.05$, $* \mathrm{p}<0.1$ 
Table 8: Placebo Treatment on Health Status

\begin{tabular}{|c|c|c|c|c|c|}
\hline & \multicolumn{5}{|c|}{ Reduced Form } \\
\hline & (1) & $(2)$ & $(3)$ & $(4)$ & $(5)$ \\
\hline Placebo(-2 years) & $\begin{array}{l}-0.022 \\
(0.029)\end{array}$ & & & & \\
\hline Placebo(-1 year $)$ & & $\begin{array}{c}0.013 \\
(0.034)\end{array}$ & & & \\
\hline Real treatment & & & $\begin{array}{l}0.077^{* *} \\
(0.033)\end{array}$ & & \\
\hline Placebo(+1 year) & & & & $\begin{array}{l}-0.031 \\
(0.034)\end{array}$ & \\
\hline Placebo $(+2$ years $)$ & & & & & $\begin{array}{l}-0.023 \\
(0.054)\end{array}$ \\
\hline Observations & 1,351 & 1,351 & 1,351 & 1,351 & 1,351 \\
\hline R-squared & 0.039 & 0.039 & 0.042 & 0.040 & 0.039 \\
\hline
\end{tabular}

Notes: Standard errors are clustered at the district level. All specifications include basic controls, marital status, amount of exercise, and pension. ${ }^{* *} \mathrm{p}<0.01,{ }^{* *} \mathrm{p}<0.05,{ }^{*} \mathrm{p}<0.1$ 